Check for updates

The BMJ

kabbasi@bmi.com Follow Kamran on Twitter@KamranAbbasi Cite this as: BMJ2021;372:n731 http://dx.doi.org/10.1136/bmj.n731 Published: 18 March 2021

\title{
Covid-19 dissenters-or the virtue in being less cheerful
}

\section{Kamran Abbasi executive editor}

Dissent is under threat. To disagree is to affront. To protest is to break the peace. To argue is to fight. Disagreement, protest, and argument help us get nearer to the truth, and marginalising them is against the very essence of science and democracy. This is happening today, all around us, and the pandemic has moved us further, faster, and for the worse.

Yet, the freedom fighters for dissent are hardy. You can hear them debating the strategy of covid elimination in the latest of our \#COVIDUnknowns webinars or in a podcast about what it means to "follow the science." ${ }^{12}$ It will be no news to these mild mannered activists that clinical trial findings are rarely well replicated in the real world, as a new research paper convinces us. ${ }^{3}$

With obesity on the rise globally, ${ }^{4}$ would the world be a better place without dissenters calling for sugar taxes? New evidence suggests not. ${ }^{5}$ Obesity was made worse by the pandemic and at the same time led to worse outcomes. ${ }^{6}$ The UK's sugar tax is a win-win: companies maintained their sales, and the sugar content of drinks dropped. ${ }^{7}$

Disagreements over the UK's Brexit policy were bitter and remain so. But perhaps nobody, except the most hardened Brexiteers, would have predicted how sharply the UK's vaccination rollout contrasts with the shambles in the European Union.

If the negative press and feeling towards the Oxford-AstraZeneca vaccine, first questioning efficacy and now safety, are political hangovers from Brexit, it is the EU populations that will lose out. Sixteen countries have suspended or paused use of the Oxford vaccine, and doses are going to waste. ${ }^{8}$ As Italy, for example, heads back into lockdown, ${ }^{9}$ the UK medicines regulator is promising to maintain its rapid approval process for vaccines and treatments. ${ }^{10}$

Vaccine hesitancy remains a problem in all territories. Among the most affected are ethnic minorities, ${ }^{11}$ including in the health and care workforce. If persuading people to be vaccinated is one answer, proper risk assessment of staff is another. ${ }^{12}$

But some of these solutions ignore the role of structural factors that disadvantage women and ethnic minorities, who are over-represented in low paid jobs in the health service. Partha Kar argues that enough is enough. ${ }^{13}$ New workforce data suggest that discrimination and its perception are in some ways worse in the NHS than four years ago. Either act on the data, he says, or stop the charade.

Hearing dissent is hard, but swimming against the tide is more difficult still, whether it is disagreeing with how lateral flow tests are used in schools, ${ }^{14}$ protesting at the UK government's secrecy over data, ${ }^{15}$ or arguing for better support for isolation of covid cases. ${ }^{16}$ What dissent and success stories both reveal are reasons to be less cheerful. And reasons to be less cheerful should not be dismissed. They are the start of the journey to a happier workforce and a healthier society.

The BMJ's covid-19 webinars. https://www.bmi.com/covid-19-webinars.

2 What should "following the science" mean for government policy [RBM] Podcast. https://podcasts.apple.com/gb/podcast/what-should-followingscience-mean-for-government-policy/id283916558?i=1000513213849.

3 Mc Cord KA, Ewald H, Agarwal A, etal. Treatment effects in randomised trials using routinely collected data for outcome assessment versus traditional trials: meta-research study. BMJ 2021;372:n450. doi: 10.1136/bmi.n450. pmid: 33658187

4 Liu B, Du Y, Wu Y, etal. Trends in obesity and adiposity measures by race or ethnicity among adults in the United States 2011-18: population based study. BMJ2021;372:n365. doi: 10.1136/bmj.n365.

5 Pell D, Mytton O, Penney TL, etal. Changes in soft drinks purchased by British households associated with the UK soft drinks industry levy: controlled interrupted time series analysis. BM/2021;372:n254 doi: 10.1136/bmj.n254. pmid: 33692200

6 Senthilingam M. Covid-19 has made the obesity epidemic worse, but failed to ignite enough action. BMJ2021;372:n411 doi: 10.1136/bmj.n411. pmid: 33664084

7 Jones A, Wu JHY, Buse K. UK's sugar tax hits the sweet spot. BMJ 2021;372:n463. doi: 10.1136/bmi.n463. pmid: 33704082

8 Mahase E. Covid-19: WHO says rollout of AstraZeneca vaccine should continue, as Europe divides over safety. BM/2021;372:n728. doi: 10.1136/bmj.n728.

9 Day M. Covid-19: Italy reimposes widespread lockdown as transmission rate rises again. BMJ2021;372:n726. doi: 10.1136/bmj.n726.

10 Coombes R. Fast track research approval "here to stay," says regulator. BMJ 2021;372:n705. doi: 10.1136/bmj.n705. pmid: 33712495

11 lacobucci G. Covid-19: NHS will keep offering vaccinations to those who refuse, says minister. BMJ2021;372:n702. doi: 10.1136/bmi.n702. pmid: 33712419

12 Khunti K, Griffiths A, Majeed A, Nagpaul C, Rao M. Assessing risk for healthcare workers during the covid-19 pandemic. BMI2021;372:n602. doi: 10.1136/bmj.n602. pmid: 33722904

13 Kar P.Partha Kar: NHS progress on diversity will need regulation and fines. BM/2021:372:n694 doi: 10.1136/bmi.n694

14 Torjesen I. What do we know about lateral flow tests and mass testing in schools?BMJ2021;372:n706

15 Mahase E. Covid-19: Government's failure to share data and face scrutiny have undermined response, say MPs. BMJ2021;372:n717 doi: 10.1136/bmj.n717. pmid: 33722799

16 Patel J, Fernandes G, Sridhar D. How can we improve self-isolation and quarantine for covid-19?BM/2021;372:n625. doi: 10.1136/bmi.n625. pmid: 33692026

This article is made freely available for use in accordance with BMJ's website terms and conditions for the duration of the covid-19 pandemic or until otherwise determined by BMJ. You may use, download and print the article for any lawful, non-commercial purpose (including text and data mining) provided that all copyright notices and trade marks are retained. 